\title{
DREAM GIRL
}

\section{Mind games.}

\section{BY SWAPNA KISHORE}

A lia's dream, splashed on the monitor, was obviously going to fail the audit. Rita, a spunky 20-year-old in a scarlet skinsuit, raced down an alley alongside innocent-eyed Bambi. Hanu-Man, a trapeze artist on gossamer threads, scooped her up; she whizzed through the air with him when BhayankarAsura grabbed her away, blood dripping from its claws. Rita squirted Jaipur pepper into its eyes.

Although Alia knew she'd have to pay a hefty penalty, she couldn't help grinning; she was thrilled to see the screen displaying the perfectly imagined Rita, her alter-ego, a character she had created herself. Pity the other characters were copyrighted.

"Watch this." The auditor twisted a knob; purple splotches filled the screen. "Your neural patterns match copyrighted neurotags at $60 \%$, well above permissible limits for residual thoughts. Your second offence, so that'll be 20,000 rupees."

This was not the time to rant about India's signing the World Copyright Act six months ago, a betrayal of the basic human right to think and dream: a law was a law. No one could think or dream of copyrighted characters without paying royalty. Even so, 20 thou! That meant skipping dinners, card payments and phone top-ups. No new shoes. Waking at 4 to take the Mumbai Metro to the office, no auto-rickshaw, and definitely no taxi.

"Can I have a copy of that recording?" Alia asked, as she signed the charge slip.

The officer frowned. "It's permitted, but viewing it will worsen your problem. I'd suggest image-guided surgical microscraping. Or pay perpetuity royalty for fan-think and fan-dreams. Because the next time you default, the penalty will be 40 ."

"I know." Alia kept her expression bashful. "The recording will remind me of what I shouldn't do."

An hour later, Alia, though poorer by 20 thou, smiled as she sipped steaming coffee at a roadside stall. Her Rita was now available in flesh - well, pixels - in her handbag. And Alia had an idea.

Mumbai Book Bazaar's window abounded with the latest graphic novels - a tease, given Alia's depleted financial state. She would have treated herself nevertheless, but today she had an idea to chase, so she passed the shop and entered the shanty-town Dharavi II.

Shakespearewallah was a dingy, musty

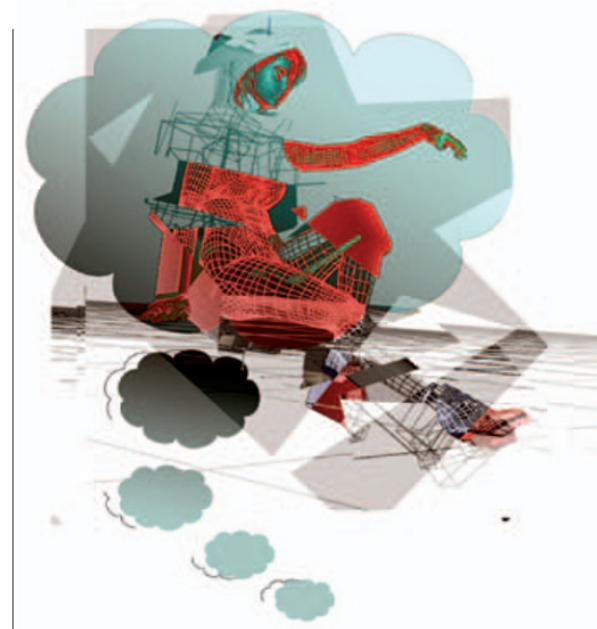

godown that stocked second-hand books that carried no neurotags. You broke no laws if you thought or dreamed about them. Creative companies, keen on collecting perpetuity royalty, had bought and destroyed most such books, but some shops like Shakespearewallah had survived. Alia indulged herself here when her budget was low.

She selected books on drawing, animation and lucid dreaming. The shopkeeper totted up the amount. "I see you here often. Are you an artist?"

"Hoping to be one."

The shopkeeper hesitated, then said: "If you want inspiration, we carry dreamsules."

A million butterflies fluttered in Alia's stomach. Dreamsules were bottled dreams. Illegal.

"You make them?" Alia asked.

"We purchase dreams and edit out any neurotags so that viewers don't get caught in dream-audits."

Alia shuddered. "I know about audits; I failed one today."

"We also offer cheap purge pills."

No way! Purge pills destroyed all neural connections that had copyright neurotags. If taken immediately after reading a copyrighted book, the pill's damage was limited, but Alia, greedy gobbler of books, incorrigible brooder and day-dreamer, had mulled over too many tagged characters for too many days. Her tags must have spread all over her brain. Purging now would be like bulldozing a building to kill a swarm of mosquitoes.

No, Alia had to choose between paying $\rightarrow$ NATURE.COM

Follow Futures on

Facebook at:

go.nature.com/mtoodm in perpetuity for every book she read; or the inevitable penalties when summoned for 'random' dream-audits.
She couldn't afford either. But hey, she could 嵌 sell her dreams.

All three of her graphic novels featured Rita Razor, a common girl with uncommon spunk. Anyone would snap this up, thought Alia, as she sat across from Mr Vandrewala, Universal Creations. He flipped through her sketches, face expressionless. Alia squirmed. She had expected more enthusiasm. "Would you like to buy them?"

"Where's the creative history?"

"Sorry?" Alia blinked.

He toyed with a crystal paperweight, his face like the scheming Sher Khan in Mowgli comics. "Rita, an orphan with magical ability, could be a female Harry Potter."

"She's not," Alia snapped, indignant.

"Did you get a certified all-clear brain audit before you started creating her? While working on this, did you refrain from copyrighted reading? Did you get official purges done after every recorded read? Can you prove your work isn't based on any copyrighted knowledge?"

"No one can prove - "

"Royalty must be paid for characters used. Without a documented, foolproof derivation, anyone can sue." Contempt laced Vandrewala's voice. "Amateurs underestimate the rigour involved."

Rigour? For two years, Alia had struggled to create Rita while also doing her day job. She'd sold her dreams for extra money and scrimped to pay perpetuity royalty to avoid dream-audit fines. Trained herself on luciddreaming. Drawing. Pixellating. All wasted.

She noticed light glinting off the paperweight when she got up: a micro-camera? How naive of her - she should have anticipated such tricks.

"Rita is my creation and has figured in my dreams for years," Alia said, anger scaffolding her voice. "My early dream-audits, archived at the Copyright Directorate, prove that."

Portfolio gripped in her hand, she walked into Mumbai Book Bazaar. "An up-to-date book on copyright law and creative works," she demanded. She'd figure out how to publish her novels; she had to, because she was already planning another one with Vandrewala as villain: Rita Razor beats Andre the Plagiarist.

You dream, girl, she told herself.

Swapna Kishore is a software consultant in Bangalore, India. She has published technical books and a business novel. She also writes speculative fiction. 